\title{
Existe uma metamorfose da História? Resposta à pergunta: como o presente se torna passado? (Berliner Tageblatt, 31 de maio de 1936)*
}

\author{
"Is there a metamorphosis of history? An answer to the question: how \\ does the present become past? (Berliner Tageblatt, May 31 $1^{\text {st }}, 1936$ )
}

\section{Johan Huizinga}

Este tema faz com que se acumulem as perguntas: como, quando, o quê? E em cada aspecto toca nas bases mais profundas da ontologia e de qualquer conhecimento filosófico. Antes de abordar o "como?", a questão do "o quê?" deveria ser solucionada. Em quê se tornará a história? Não um acontecimento, não uma época, não um período enquanto tais. Milhares de eventos jamais se tornam história, eles repousam, embora talvez ainda possam ser conhecidos, num vago esquecimento sob as profundezas do histórico. A história só existe à medida em que um ser humano ou uma sociedade passa a observar determinados eventos. Tudo o que aconteceu 306 já é passado no instante em que pode ser observado. Se a "distância" já se constituiu, depende do observador. Eu posso perceber minha véspera como história e minha infância como presente. A fronteira entre história e presente radica no olhar do momento, ou, melhor dizendo, não há fronteira alguma. Não existe o agora, só passado e futuro, e a essência do que supomos ser o hoje assenta em sua historicidade.

Existe uma metamorfose da história? Para que isso ocorra, é necessário que já exista algo dotado de uma essência. Porém, o presente só adquire sua essência histórica, e que é única, no processo de elaboração formal (Formgebung) que se realiza por intermédio do observador. ${ }^{1}$ Esta elaboração formal não se dá ininterruptamente e por si mesma. Onde faltam observadores capazes de ver e pensar historicamente, os destinos de um povo não adquirem forma alguma.

Pode a história assumir formas falsas? - Sim, infelizmente. - Existe uma forma identificável e inteiramente verdadeira da história? - Para nós, seres humanos tolos e cegos, não. - Deve-se, então, num despreocupado relativismo,

\footnotetext{
* Posteriormente publicado em: HUIZINGA, Johan. Wie wird Gegenwart Vergangenheit? In: Geschichte und Kultur. Gesammelte Aufsätze. Stuttgart: Alfred Kröner, 1954, p. 119-125. Tradução: Michel Kors e Sérgio da Mata.

${ }^{1}$ Nota dos tradutores: Sobre o conceito de Formgebung, ver a tese de doutoramento de DAMAS, Naira. As formas da História: Johan Huizinga e a História da Cultura como Morfologia. Tese (Doutorado em História Social). Rio de Janeiro: Universidade Federal do Rio de Janeiro, 2013, 73-84. Huizinga reconheceu publicamente o quanto devia ao historiador e crítico literário André Jolles, cujo estudo Formas simples dizia conhecer desde antes de sua publicação. Nesta obra, Jolles emprega o conceito de Formbestimmung, análogo ao de Huizinga. Cf.: JOLLES, André. Einfache Formen. Tübingen: Max Niemeyer, 1974, p. 6-9.
} 
duvidar da verdade histórica? - Não, o indivíduo faz seus juízos e tem sua consciência, e isso é o suficiente para a consciência pessoal da verdade.

O que gera a necessidade espiritual de se conferir uma forma histórica às coisas? - Que coisas? - As coisas que nos dizem respeito. - E que coisas nos dizem respeito?...

Aqui a resposta vacila. Pois nenhum conceito, por geral que seja, diz o suficiente para expressar a abrangência e a profundidade do anseio pelo conhecimento histórico: nem povo, nem Estado, nem espírito, nem cultura, nem o mundo, nem a humanidade. O conhecimento histórico é uma necessidade vital, e como tal escapa a uma motivação exata.

Caso se quisesse limitar um tema que é, talvez, demasiado amplo, à questão: sob quais condições um passado histórico pode ser observado e tido como fechado? - então se mostraria mais uma vez que a delimitação temporal não faz sentido. Tais condições residem apenas na clareza do espírito e na serenidade do discernimento do observador. Apesar de toda sua intensidade, é somente no momento em que o olhar tenta abarcar com absoluta precisão o próximo e o longínquo, para, contudo, meramente tangenciar a ambos na vastidão do infinito, é que surge a história.

Assim, caso o esforço de rememoração de um feito histórico esteja tensionado entre as exigências de um sistema de forças preexistente, as necessidades da hora e as correspondentes visões de futuro de seus heróis, no decorrer dessas constatações as relações temporais dos acontecimentos históricos passam por um curioso deslocamento. Mas a tese inicial se mantém: o presente, visto do ponto de vista puramente temporal, torna-se passado num piscar de olhos. A chance é empregada ou desperdiçada. Com isso se justifica o historiador. Sua pena só é capaz de oferecer uma ideia geral do que já aconteceu. Mesmo ante o presente o historiador tem a ver com o passado. Mas o próprio passado se transforma quão mais profundamente o encaramos, e mais evidente se torna, para o historiador, o caráter convencionalmente romanesco que lhe é atribuído. Aquilo a que se deve chamar de passado, em comparação com o presente imediato, é, em sua parte mais fundamental, mero presente. Pois do ponto de vista do calendário, toda a Alemanha, todo povo, Estado, Império e inclusive suas mais recentes manifestações pertencem igualmente ao passado. Tal como, por exemplo, o nosso próprio eu, por meio do qual nos identificamos já que carregamos nosso nome conosco. Igualmente, entretanto, tais criações e inclusive nossa personalidade emergem da maneira mais clara e visível no puro presente, a saber: como forças e formas vivas. Isto é: os próprios sujeitos históricos participam da modalidade específica de atemporalidade da vida histórica. Não se trata daquela já muito discutida atemporalidade filosófica dos valores e verdades atemporalmente válidos, mas da superação do tempo da individualidade e da duração históricas: toda a força viva de um povo, toda configuração e forma de suas obras mais elevadas surgem a partir do que há de passado no presente e no futuro. Um povo não é algo que pertença ao hoje ou ao ontem. Em sua trajetória ele não se mantém 
intocado pelo seu destino, mas permanece o mesmo em meio a todas as transformações por que passa seu presente, vitorioso no confronto com o fluxo do tempo como um pico coberto por neves eternas, acima do qual os verões se sucedem. Tudo o que acontece, repetimos, acontece nele. Nesse sentido, tudo o que tem duração, embora seu aparecimento tenha ficado para trás, é presente vivo. É realidade por excelência, uma vez que produz efeitos. Não apenas repousa eternamente como o passado, mas enquanto se mantém força viva permanece e se preserva no ser.

Mas o passado não mantém essa notável e íntima relação apenas com o presente. Ainda mais peculiar é a sua relação com o futuro. A razão não repousa apenas na tão discutida subjetividade das concepções históricas. Não, a linha do passado revela-se ainda mais paradoxal, apesar de já estabelecida, uma vez que não independe do futuro. É difícil selecionar exemplos. O esquecido é desbotado, e o atual complicado. Nós os vemos como mera ficção.

Se admitirmos que um estado tampão seja estabelecido por um tratado de paz entre certas potências, e que este estado já fora uma vez anexado por seus vizinhos, não obstante ele preserva a orgulhosa memória nacional de seus antigos tempos de liberdade. Caso esta restauração dure séculos então pode chegar o instante em que, graças a uma certa proporção dos períodos, as épocas de servidão são tomadas como meros episódios. Mas caso num espaço de tempo relativamente curto este estado-tampão seja submetido aos colossos que o cercam, então sua restauração outrora ocorrida se torna um episódio 308 que não desperta qualquer atenção. Aquilo que de mais objetivo parecia existir no passado, a curvatura da vida, é precisamente o que aqui se revela como uma função do futuro. Formas se dissolvem em formas mais abrangentes.

Assim poderiam ser respondidas as perguntas acima colocadas. Eu respeito sua sequência. Nada acontece mais rapidamente do que o naufrágio do presente e do atual no passado e no "ontem".

Torna-se história, num sentido forte, somente um evento decisivo para o destino de uma coletividade. Certamente, contudo, o histórico pode ter ainda três sentidos distintos. "Meramente histórico" é o evento superficial. Então torna-se história o que foi decidido, no sentido de não ser mais questionado. O ocorrido não é mais um tema, mas a base, o fundamento, o trampolim de novas decisões. Finalmente, torna-se histórico o grande feito que permanece não apenas na memória mas que ainda é uma realidade, ao menos enquanto produz efeitos, mesmo que ocorrido há séculos. Aqui foi a história quem "decidiu", a saber: sobre um destino. As ações que não se transformam em destino são colocadas na balança e consideradas leves demais. ${ }^{2}$ São rapidamente esquecidas. A memória histórica salta facilmente por sobre épocas inteiras. É aqui que se acham os "eventos diários" dos quais permanece apenas a "história do presente", não como aquilo que ocorreu na véspera mas como algo ainda "vivo". A "distância temporal" do olhar

\footnotetext{
${ }^{2}$ Nota dos tradutores: Huizinga remete aqui a uma passagem do profeta Daniel $(5,27)$ : "foste pesado na balança e considerado leve demais". Trata-se de uma expressão relativamente comum em holandês, e que o autor apenas transpôs ao idioma alemão (sind gewogen und zu leicht gefunden).
} 
histórico é apenas um alívio superficial para uma atividade que configura a verdadeira virtude do historiador: avaliar os acontecimentos de acordo com sua importância e com a capacidade de que dispõem, no longo prazo, de produzir novas formas de vida. Tal força se manifesta como duração em meio a todas as transmutações das circunstâncias. Nos povos, como nas árvores. Quanto maior a quantidade daquilo que, nestas como naqueles, se conserva e desenvolve de maneira viva, tanto mais numerosas as porções de presente a emergir no futuro. 